\title{
Menstrual pattern amongst adolescent girls: a cross sectional study from Raichur, Karnataka
}

\author{
Pavani Marri ${ }^{1}$, Monisha Deepika Ravipati ${ }^{1}$, Lavanya Bolla ${ }^{1 *}$, Anant A. Takalkar ${ }^{2}$
}

\begin{abstract}
${ }^{1}$ Department of Obstetrics and Gynaecology, Navodaya Medical College Hospital and Research Centre, Raichur, Karnataka, India

${ }^{2}$ Department of Community Medicine, MIMSR Medical College and YCRH, Latur, Maharashtra, India
\end{abstract}

Received: 10 November 2021

Revised: 22 November 2021

Accepted: 23 November 2021

*Correspondence:

Dr. Lavanya Bolla,

E-mail: vytlalavanya77@gmail.com

Copyright: ( ) the author(s), publisher and licensee Medip Academy. This is an open-access article distributed under the terms of the Creative Commons Attribution Non-Commercial License, which permits unrestricted non-commercial use, distribution, and reproduction in any medium, provided the original work is properly cited.

\section{ABSTRACT}

Background: Menstrual disorders in adolescent age are quite different than in adult women, both for diagnostic and therapeutic management. We need to take into account the problems in normal initiation of menarche, hematological problems, general endocrine problems, and fragile emotional status at this tender age. The objective of the study was to study the patterns of menstrual disorders in adolescent girls.

Methods: Cross sectional observational study was carried out in 200 adolescent girls, aged 12 to 19 years, among the students of S.R.P.S PU college and the district government Girls' school in Raichur during the period of January 2017 to December 2017. A pre-structured questionnaire was used and data was analysed using Statistical package for social sciences (SPSS) 23.0 version.

Results: Majority of the girls in our study were from 17-18 years age group (55\%). The mean age of menarche was $13.2 \pm 0.9$ years. Cycle length of $<21$ days was found in $4(2 \%)$ of cases, $143(71.5 \%)$ had 21-35 days cycle and $10(5 \%)$ had >35 days cycle length. Majority had normal cycle length. Dysmenorrhea was found in 84 (42\%) students. Premenstrual symptoms like tiredness were noted in $14(7 \%)$ of cases, pain in the legs in $10(5 \%)$, irritability in $8(4 \%)$, lack of interest in work and play in $7(3.5 \%)$, low back pain in $6(3 \%)$, low/depressed mood in $6(3 \%)$, anger in $4(2 \%)$, anxiety in $4(2 \%)$, difficulty in concentrating in $2(1 \%)$, nausealvomiting were noted in $2(1 \%)$.

Conclusions: Prevalence of dysmenorrhea was $42 \%$. Premenstrual symptoms like tiredness were noted in majority of the girls $7 \%$, pain in the legs in $5 \%$, irritability in $4 \%$.

Keywords: Adolescent girls, Menstrual pattern

\section{INTRODUCTION}

Menstrual disorders in adolescent age are quite different than in adult women, both for diagnostic and therapeutic management. We need to take into account the problems in normal initiation of menarche, hematological problems, general endocrine problems, and fragile emotional status at this tender age. Adolescent girls constitute nearly one tenth of Indian population and form a crucial segment of the society. ${ }^{1}$ Their current nutritional status will decide the well-being of the present as well as the future generations. Under-nutrition among these girls is associated with reduced lean body mass, lack of muscular strength and decreased work capacity. Moreover, under-fed girls are at risk of being stunted mothers who are likely to suffer obstetric complications and to deliver low birth weight babies. In the absence of effective nutritional interventions, the low-birth-weight girls become the next generation of stunted mothers, thus, perpetuating the vicious cycle of malnutrition. ${ }^{2}$ 
Adolescents are generally considered healthier than the very young or the very old, and hence their health problems were not given much prominence. Adolescent girls constitute a more vulnerable group, particularly in developing countries, where they are traditionally married at an early age and exposed to greater risk of reproductive morbidity and mortality. ${ }^{3}$

Anaemia is a highly prevalent disease in developing countries. Anaemia is common during adolescence due to demands of increased growth and menstrual blood loss. Studies have shown that iron deficiency exists in both clinical as well as subclinical forms in adolescent girls. In adolescent girls, the onset of menstruation can alter the iron status of an individual not only by creating a demand for more iron due to blood loss but also due to the proinflammatory nature of menstrual cycle itself. ${ }^{4}$ Reproductive morbidities such as dysmenorrhoea, premenstrual syndrome, irregular menses, excessive bleeding during menstruation etc. are common in adolescent girls. In spite of this, health care seeking for reproductive morbidities is very low. Most of the adolescent girls remain silent without seeking health care. If these are not treated early, they could lead to various reproductive disabilities. $^{5}$

Hence the present cross-sectional study was carried out with the objective to study the patterns of menstrual disorders in adolescent girls.

\section{Objective}

To study the patterns of menstrual disorders in adolescent girls.

\section{METHODS}

The study was cross sectional observational study. The study was conducted at S.R.P.S PU college and the district government girls' school in Raichur. The study was conducted as one year-cross sectional study: from January 2017 to December 2017.

\section{Source of data}

The study involved adolescent girls, aged 12 to 19 years, among the students of S.R.P.S PU college and the district government girls' school in Raichur.

\section{Method of collection of data}

Study commenced after obtaining consent/permission from the authorizing body i.e., the respective principal/teacher.

\section{Data was collected by}

A pre prepared questionnaire. Detailed history taking, including socio-economic, cultural and environmental history. General physical examination. Systemic examination. Gynaecological examination (if required).

\section{Sample size}

200 adolescent school going girls in the educational institutions.

\section{Inclusion criteria}

Adolescent girls aged between 12 and 19 years.

\section{Exclusion criteria}

Girls aged less than 12 years or more than 19 years.

This is a questionnaire based, cross sectional study in adolescent school girls. With questions related to menarche, last menstrual period, regularity of cycles, cycle length, duration, pain during menstruation, amount of bleeding, family history, premenstrual symptoms, family history, medical history and school absenteeism and effect of menstrual cycles on daily activities. Height, weight was recorded and BMI was calculated and values were classified based on WHO growth reference curves for school aged children and adolescents. 29 General physical examination was done after taking consent. Pallor, nutritional status, hirsutism, acne, pubertal changes, deepening of voice, secondary sexual characters including breast changes, pubic, axillary hair changes as per Tanner's staging were examined. Thyroid examination was done.

\section{Statistical method}

All characteristics were summarized descriptively. For continuous variables, the summary statistics of mean \pm standard deviation (SD) were used. For categorical data, the number and percentage were used in the data summaries and diagrammatic presentation. Chi-square $(\chi 2)$ test was used for association between two categorical variables. In cases of more than $30 \%$ cell frequency $<5$, Freeman-Halton Fisher exact test was employed to determine the significance of differences between groups for categorical data. If the $p<0.05$, then the results were considered to be statistically significant otherwise, it was considered as not statistically significant. Data were analyzed using Statistical package for social sciences (SPSS) software v.23.0. and Microsoft office 2007.

\section{RESULTS}

Majority of the girls in our study were from 17-18 years age group (55\%) followed by $34 \%$ from $15-16$ years age group. The mean age of girls in our study was $16.7 \pm 1.3$ years.

A total $39 \%$ of the girls achieved menarche at the age of 13 years and $36 \%$ achieved it at 14 years. The mean age of menarche was $13.2 \pm 0.9$ years. 
Cycle duration of 3-6 days was seen in most cases i.e.186 $(93 \%),<3$ days in $4(2 \%)$ of cases and a duration of more than 7 days in $10(5 \%)$ cases.

Cycle length of <21 days was found in $4(2 \%)$ of cases, $143(71.5 \%)$ had 21-35 days cycle and $10(5 \%)$ had $>35$ days cycle length. Most of the students had normal cycle length.

Dysmenorrhea was found in $84(42 \%)$ students. It is the most common menstrual disorder in our study group. Menorrhagia was seen in $26(13 \%)$ of students. It is the next common menstrual disorder. $10(5 \%)$ cases of oligomenorrhea were seen. $7(3.5 \%)$ cases had hypomenorrhea. Polymenorrhoea was seen in $4(2 \%)$ cases.

Of the Premenstrual symptoms, tiredness was noted in 14 $(7 \%)$ of cases, pain in the legs in $10(5 \%)$, irritability in 8 $(4 \%)$, lack of interest in work and play in $7(3.5 \%)$, low back pain in $6(3 \%)$, low/depressed mood in $6(3 \%)$, anger in $4(2 \%)$, anxiety in $4(2 \%)$, difficulty in concentrating in $2(1 \%)$, nausealvomiting were noted in $2(1 \%)$

\section{DISCUSSION}

In our study, conducted in Raichur, 200 adolescent school girls in the age group of 12-19 years were studied during the period of January 2017 to December 2017.

Table 1: Distribution according to age group.

\begin{tabular}{|lll|}
\hline Age (years) & $\begin{array}{l}\text { Number of } \\
\text { cases }\end{array}$ & Percentage \\
\hline $\mathbf{1 3 - 1 4}$ & 16 & 8 \\
\hline $\mathbf{1 5 - 1 6}$ & 68 & 34 \\
\hline $\mathbf{1 7 - 1 8}$ & 110 & 55 \\
\hline$>\mathbf{1 8}$ & 6 & 3 \\
\hline Total & 200 & 100 \\
\hline
\end{tabular}

In the study done by Lee et al mean age group was $15.4 \pm 1.8$ years and in Rigon et al 7 study mean age group was $17.1 \pm 1.4 y r s$. The mean age of girls in our study, lies between these two studies. It was $16.7 \pm 1.3$ years. ${ }^{6}$

Table 2: Distribution of cases according to age of menarche.

\begin{tabular}{|lll|}
\hline $\begin{array}{l}\text { Age of Menarche } \\
\text { (years) }\end{array}$ & $\begin{array}{l}\text { Number of } \\
\text { cases }\end{array}$ & Percentage \\
\hline $\mathbf{1 1}$ & 8 & 4 \\
\hline $\mathbf{1 2}$ & 36 & 18 \\
\hline $\mathbf{1 3}$ & 78 & 39 \\
\hline $\mathbf{1 4}$ & 72 & 36 \\
\hline $\mathbf{1 5}$ & 6 & 3 \\
\hline Total & 200 & 100 \\
\hline
\end{tabular}

In the study done by Lee et al mean age of menarche was $12.3 \pm 1.1$ years and in Rigon et al study mean age of menarche was $12.4 \pm 1.3$ years. $^{6,7}$ The mean age of menarche in girls in our study was slightly higher. It was $13.2 \pm 0.9$ years.

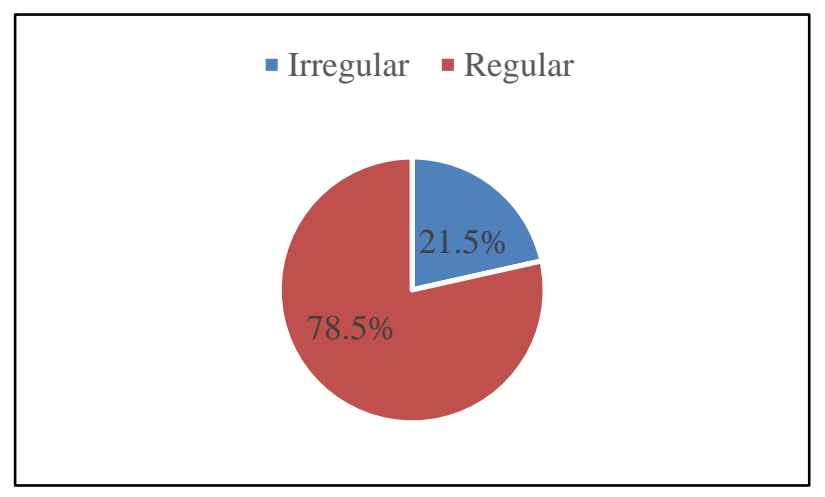

Figure 1: Pattern of mensturation.

Table 3: Distribution of cases according to duration of menstrual cycle.

\begin{tabular}{|lll|}
\hline $\begin{array}{l}\text { Cycle duration } \\
\text { (days) }\end{array}$ & $\begin{array}{l}\text { Number of } \\
\text { cases }\end{array}$ & Percentage \\
\hline$<\mathbf{3}$ & 4 & 2 \\
\hline $\mathbf{3}$ to $\mathbf{7}$ & 186 & 93 \\
\hline $\mathbf{7}$ & 10 & 5 \\
\hline Total & 200 & 100 \\
\hline
\end{tabular}

Table 4: Distribution of cases according to length of menstrual cycle.

\begin{tabular}{|lll|}
\hline $\begin{array}{l}\text { Cycle length } \\
\text { (days) }\end{array}$ & $\begin{array}{l}\text { Number of } \\
\text { cases }\end{array}$ & Percentage \\
\hline$<\mathbf{2 1}$ & 4 & 2 \\
\hline $\mathbf{2 1 - 3 5}$ & 143 & 71.50 \\
\hline$>\mathbf{3 5}$ & 10 & 5 \\
\hline Total & 157 & 100 \\
\hline
\end{tabular}

In the study done by Jaget et al, 58 (29\%) had irregular cycles and $142(71 \%)$ had regular cycles. ${ }^{8}$ Negi et al found irregular cycles in $135(28.72 \%)$ and regular cycles in 335 $(71.28 \%)^{9}$

Table 5: Distribution of cases according to menstrual disorders.

\begin{tabular}{|lll|}
\hline $\begin{array}{l}\text { Menstrual } \\
\text { disorder }\end{array}$ & $\begin{array}{l}\text { Number of } \\
\text { cases }\end{array}$ & Percentage \\
\hline Polymenorrhoea & 4 & 2 \\
\hline Hypomenorrhea & 7 & 3.5 \\
\hline Oligomenorrhea & 10 & 5 \\
\hline Menorrhagia & 26 & 13 \\
\hline Dysmenorrhea & 84 & 42 \\
\hline
\end{tabular}

In our study, cycles were regular in 157 (78.5\%) girls and irregular in $43(21.5 \%)$. The incidence of regular cycles was slightly higher in our group. 
Table 6: Distribution of cases according to premenstrual symptoms.

\begin{tabular}{|lll|}
\hline $\begin{array}{l}\text { Premenstrual } \\
\text { symptoms }\end{array}$ & $\begin{array}{l}\text { Number } \\
\text { of cases }\end{array}$ & Percentage \\
\hline Nausea, vomiting & 2 & 1 \\
\hline Irritability & 8 & 4 \\
\hline Anger & 4 & 2 \\
\hline Anxiety & 4 & 2 \\
\hline Pain in the legs & 10 & 5 \\
\hline Tiredness & 14 & 7 \\
\hline Low back pain & 6 & 3 \\
\hline $\begin{array}{l}\text { Lack of interest in } \\
\text { work and play }\end{array}$ & 7 & 3.5 \\
\hline $\begin{array}{l}\text { Difficulty in } \\
\text { concentrating }\end{array}$ & 2 & 1 \\
\hline Low/depressed mood & 6 & 3 \\
\hline
\end{tabular}

Table 7: Comparing mean age of participating students from other studies.

\begin{tabular}{|lll|}
\hline Study & Sample Size & $\begin{array}{l}\text { Mean age of } \\
\text { subjects }\end{array}$ \\
\hline${\text { Lee et } \mathbf{a l}^{\mathbf{6}}}^{\mathbf{6}}$ & 2247 & $15.4 \pm 1.8$ years \\
\hline Rigon et $\mathbf{a l}^{7}$ & 4892 & $17.1 \pm 1.4$ years \\
\hline Our study & 200 & $16.7 \pm 1.3$ years \\
\hline
\end{tabular}

Table 8: Comparing mean age of menarche with other studies.

\begin{tabular}{|lll|}
\hline Study & Sample Size & $\begin{array}{l}\text { Mean Age of } \\
\text { menarche }\end{array}$ \\
\hline${\text { Lee et } \mathbf{a l}^{\mathbf{6}}}^{\text {Rigon et } \mathbf{~ a l}^{\mathbf{7}}}$ & 2247 & $12.3 \pm 1.1$ years \\
\hline Our study & 4892 & $12.4 \pm 1.3$ years \\
\hline
\end{tabular}

In the study by Jaget et al, $16(8 \%)$ had duration <3 days, 3-6 days duration was seen in $169(84.5 \%)$ and $15(7.5 \%)$ had $>7$ days duration. ${ }^{8}$ Dambhare et al study had $<3$ days duration in $9(1.6 \%)$ girls, 3-6 days duration $545(97.15 \%)$ girls and $7(1.25 \%)$ with $>7$ days duration. ${ }^{10}$

Table 10: Cycle duration compared to other studies' findings.

\begin{tabular}{|lllll|}
\hline Study & $\begin{array}{l}\text { Sampl } \\
\text { e size }\end{array}$ & $\begin{array}{l}<\mathbf{3} \\
\text { days }\end{array}$ & $\begin{array}{l}\mathbf{3 - 6} \\
\text { days }\end{array}$ & $>$ 7 days \\
\hline $\begin{array}{l}\text { Jaget et } \\
\text { al }^{\mathbf{8}}\end{array}$ & 200 & $\begin{array}{l}16 \\
(8 \%)\end{array}$ & $\begin{array}{l}169 \\
84.5 \%\end{array}$ & $15(7.5 \%)$ \\
\hline $\begin{array}{l}\text { Dambha } \\
\text { re et al }\end{array}$ & 561 & $\begin{array}{l}\mathbf{1 0} \\
(1.6 \%)\end{array}$ & $\begin{array}{l}545 \\
97.15 \%\end{array}$ & $7(1.25 \%)$ \\
\hline $\begin{array}{l}\text { Our } \\
\text { study }\end{array}$ & 200 & $4(2 \%)$ & $\begin{array}{l}186 \\
93 \%\end{array}$ & $10(5 \%)$ \\
\hline
\end{tabular}

Our study, findings had values lying between these two studies with cycle duration of 3-6 days in $186(93 \%),<3$ days in $4(2 \%)$ of cases and a duration of more than 7 days in $10(5 \%)$ cases.

\section{Menstrual disorders}

Dysmenorrhea was noted in the studies done by Priya et al, Kulkarni et al, Rathod et al, Deo et al as 325 (65\%), 120 $(53.6 \%), 213(32.5 \%)$ and $50(31.64 \%) .{ }^{11-14}$ In our study, it was found in $84(42 \%)$ students, falling within the range of values detected in these studies.

Menorrhagia was noted in $945(17 \%), 55$ (11\%), 16 $(10.13 \%)$ in the studies done by Agarwal et al15, Priya et al and Deo et al. ${ }^{11,14}$ In our study it was found to be within the same range. It was recorded in $26(13 \%)$ of students.

Oligomenorrhoea was seen in $850(15.3 \%), 80(16 \%)$ in studies by Agarwal et al and Priya et al while no cases were detected in study by Deo et al. In our study, fewer cases were noted. ${ }^{11,14,15}$ There were $10(5 \%)$ cases of oligomenorrhea

Polymenorrhoea Agarwal et al, Priya et al, Deo et al found Polymenorrhoea in $111(2 \%), 20(4 \%), 2$ (1.26\%) cases respectively. ${ }^{11,14,15}$ Our study finding was similar to these studies with $4(2 \%)$ cases.

Hypomenorrhea was found in $30(6 \%), 6(3.79 \%)$ in studies done by Priya et al and Deo et al respectively while Agarwal et al found no cases in their study. ${ }^{11,14,15}$ Our study showed 7 (3.5\%) cases, a value lying between these two values.

\section{Premenstrual symptoms}

In a study conducted by Bakhtiari et al, of 536 cases tiredness was noted in $269(50.1 \%)$ of cases, pain in the legs in $56(10.4 \%)$, irritability in $72(13.4 \%)$, lack of interest in work and play was not detected, low back pain in $148(27.6 \%)$, low/depressed mood in $43(8 \%)$, anger in $72(13.4 \%)$, anxiety in $72(13.4 \%)$, difficulty in concentrating was not detected, nausea/vomiting were noted in $27(5 \%) .{ }^{16}$

In our study, out of 200 patients, $24(12 \%)$ cases had premenstrual symptoms. Of the premenstrual symptoms, tiredness was noted in $14(7 \%)$ cases, pain in the legs in 10 $(5 \%)$, irritability in $8(4 \%)$, lack of interest in work and play in $7(3.5 \%)$, low back pain in $6(3 \%)$, low/depressed mood in $6(3 \%)$, anger in $4(2 \%)$, anxiety in $4(2 \%)$, difficulty in concentrating in $2(1 \%)$, nausealvomiting were noted in $2(1 \%)$.

\section{CONCLUSION}

Premenstrual symptoms like tiredness was noted in majority of the girls $7 \%$, pain in the legs in $5 \%$, irritability in $4 \%$. In our study, menstrual disorders like dysmenorrhea affected $42 \%$ of girls, menorrhagia affected $13 \%$ of girls, oligomenorrhea affected 5\% girls, hypomenorrhea affected $3.5 \%$ and polymenorrhoea affected $2 \%$ of the girls. Therefore, it is vital to understand the existing pattern of menstrual disorders among adolescent girls and further 
plan on education and evaluation. It thus helps in promoting health in young girls. It is important to educate the adolescents about normal menstrual cycle and menstrual hygiene. They should be aware about abnormal menstrual patterns and proceed for timely evaluation and management to avoid complications in general health, psychosocial health and reproductive health.

Funding: No funding sources

Conflict of interest: None declared

Ethical approval: The study was approved by the Institutional Ethics Committee

\section{REFERENCES}

1. Jeffcoate N, Malhotra N. Jeffcoate's principles of gynaecology. 8th ed. New Delhi: Jaypee Brothers Medical Publ. 2014;P.99.

2. Malhotra A, Passi SJ. Diet quality and nutritional status of rural adolescent girl beneficiaries of ICDS in north India. Asia Pacific Journal of Clinical Nutrition. 2007;16 (1):8-16.

3. Joseph GA, Bhattacharji S, Joseph A, Rao PSS. General and Reproductive Health of Adolescent Girls in Rural South India. Indian Journal of Paediatrics. 1997;34:242-5.

4. Gunasekaran D, Swapna K, Venkatesh C, Soundararajan P. Iron stores and menstruation in healthy adolescent girls - pilot study. Current Paediatrics Research. 2012;16(2):153-5.

5. Nair MKC. Adolescent sexual and reproductive health. Indian Journal of Pediatrics. 2004;41(1):7-13.

6. Lee LK, Chen PCY, Lee KK, Kaur J. Menstruation among adolescent girls in Malaysia: a cross-sectional school survey. Singapore Med J. 2006;47(10)(869):18.

7. Rigon F, De Sanctis V, Bernasconi S, Bianchin L, Bona $\mathrm{G}$, Bozzola $\mathrm{M}$ et al. Menstrual pattern and menstrual disorders among adolescents: an update of the Italian data. Italian Journal of Pediatrics. 2012;38(1):38.
8. Lakkawar JN, Arthi N, Alaganandam P. A Study of Menstrual Disorders in Medical Students and its Correlation with Biological Variables. Scholars Journal of Applied Medical Sciences (SJAMS). 2014;2(6E):3165- 75 .

9. Negi P, Mishra A, Lakhera P. Menstrual abnormalities and their association with lifestyle pattern in adolescent girls of Garhwal, India. Journal of Family Medicine and Primary Care. 2017;7(4):804.

10. Dambhare D, Wagh S, Dudhe J. Age at Menarche and Menstrual Cycle Pattern among School Adolescent Girls in Central India. Global Journal of Health Science. 2011;4(1).

11. Priya S, Alliratnam A, Shankar R. Menstrual problems and hygiene among rural adolescent girls of Tamil Nadu-A cross sectional study. Indian Journal of Obstetrics and Gynecology Research. 2016;3(2):126.

12. Kulkarni M, Durge P. Reproductive Health Morbidities among Adolescent Girls: Breaking the Silence!. Studies on Ethno-Medicine. 2011;5(3):1658.

13. Rathod A, Chavan R, Pajai S, Bhagat V, Thool P. Gynecological Problems of Adolescent Girls Attending Outpatient Department at Tertiary Care Center with Evaluation of Cases of Puberty Menorrhagia Requiring Hospitalization. The Journal of Obstetrics and Gynecology of India. 2015;66(S1):400-6.

14. Deo SD, Ghattargi C. Menstrual problems in adolescent school girls: A comparitive study in urban and rural area. Indian J Prev Soc Med. 2017;38:1-2.

15. Agarwal A, Venkat A. Questionnaire Study on Menstrual Disorders in Adolescent Girls in Singapore. Journal of Pediatric and Adolescent Gynecology. 2009;22(6):365-71.

16. Bakhtiari A, Omidvar S, Amiri F, Begum K. A study on menstruation of Indian adolescent girls in an urban area of South India. Journal of Family Medicine and Primary Care. 2017;7(4):698.

Cite this article as: Marri $\mathrm{P}$, Ravipati MD, Bolla L, Takalkar AA. Menstrual pattern amongst adolescent girls: a cross sectional study from Raichur,

Karnataka. Int J Reprod Contracept Obstet Gynecol 2021;10:4429-33. 